\title{
Bibliometric Analysis on Social Entrepreneurship Specialized Journals
}

\author{
YUSUF ISKANDAR ${ }^{1}$, JOELIATY JOELIATY ${ }^{2}$, UMI KALTUM $^{3}$, HILMIANA HILMIANA $^{4}$ \\ Faculty of Economics and Business \\ Universitas Padjadjaran \\ Bandung \\ INDONESIA
}

\begin{abstract}
The topics of social entrepreneurship have increased considerably time by time. Social entrepreneurship becomes an engaging, specific theme in the field of entrepreneurship research. The purpose of this paper is to analyze how are social entrepreneurship articles classified. Then, to know the trend of social entrepreneurship research, to know which research topics are the subject of more publications, and to analyze future social entrepreneurship topics that provide opportunities for further investigation. There are two journals from leading publishers that specifically offer a publishing platform for social entrepreneurship. There are many articles in these two journals that can specifically give us information about the development of this entrepreneurial topic. We have reviewed this database and attempted to classify materials using VOSviewer software. There are several article groupings into sub-topic sections.
\end{abstract}

Key-Words: - social entrepreneurship, bibliometric analysis, publish or perish, mendeley, vosviewer.

Received: March 23, 2021. Revised: August 7, 2021. Accepted: August 16, 2021. Published: September 2, 2021.

\section{Introduction}

Social entrepreneurship has developed into something interesting in the twenty-first century [1]. This phenomenon occurs because the main focus is not to optimize profits but also for community building [2]. Some experts such as [3] and [4] argue that social entrepreneurship is suitable for development and has a decisive role in solving social problems. Social entrepreneurship has become a new inspiration in developing paradigms related to non-governmental development organizations. [5] see the potential of social entrepreneurship in producing something promising, especially in social issues such as increasing income in traditional business activities. One of the most prominent people and one of the best instances of social entrepreneurship is the 2006 Nobel Peace Prize recipient, Muhammad Yunus. He developed the very successful Grameen Bank in Bangladesh to provide credit to the underprivileged to help them move out of poverty.

Social entrepreneurship is a growing topic and is increasingly being studied by academics today [6].

There have been two journals explicitly dedicated to social entrepreneurship, namely the Journal of
Social Entrepreneurship and the Social Enterprise Journal. The theme of social entrepreneurship is also commonly found in other entrepreneurial journals. Based on the results of previous studies, the literature on social entrepreneurship is considered to be in a challenging and developing way, where analysis of the status and legitimacy of the field still requires further study [7], [6], [8]. Researchers have not yet determined the amount or quality of research carried out in this field [9]. Based on the statements of the previous researchers, it is necessary to have a recent study of the bibliometrics from the term of social entrepreneurship.

Social entrepreneurship has been the subject of discussion reviewed by previous researchers. Some academics such as [10], [11], and [12] have tried to discuss social entrepreneurship by doing a general review to be used as the scientific development of this topic. [8] provides an overview of research on social entrepreneurship through a bibliometric study and the use of [13] framework to determine the evolution of social entrepreneurship. The study is based on all conceptual and research papers published in the Social Enterprise Journal from 2005 to 2017. [6] also made an overview of social entrepreneurship 
through bibliometric analysis using the Web of Science database article.

To the best of our knowledge, no bibliometric analysis of the social entrepreneurship topics has been conducted from the two journals indexed by Scopus specialized in social entrepreneurship research. Those two social entrepreneurship specialized journals are the Journal of Social Entrepreneurship and Social Enterprise Journal. The purpose of this paper is to answer the following questions:

1) How are social entrepreneurship articles classified?

2) What is the trend of social entrepreneurship research?

3) Which research topics are the subject of more publications?

4) What are future social entrepreneurship topics that provide opportunities for further research?

This paper was prepared to start with a literature review of the term social entrepreneurship based on the results of previous studies. Besides, the research objectives are also presented in Section 1. In Section 2, the definition of social entrepreneurship and the existing review of the term social entrepreneurship. The methodology used to carry out bibliometric analysis includes the method steps related to using databases from the three journals in Section 3. Section 4 presents the results using VOSviewer. Research recommendations, conclusions, and limitations appear in Section 5.

The social dimension of entrepreneurship was developed by [14], who had not yet found a satisfying discovery. Furthermore, [3] revealed that at that time, the term social entrepreneurship was considered new. However, the practice of social entrepreneurship was not new. The statement is also in line with [15]. [16] revealed that social entrepreneurship is an approach of nonprofit businesses and social economy and is another form of entrepreneurship in general.

Social enterprises need to have a strategy to strengthen their position in the open market. The strategy also needed to make an impact because one of the visions of social enterprises is to create a sustainable development of economic and social causes [17]. Also, [3] revealed that there are fundamental differences between social entrepreneurs and businesses. In social entrepreneurship, the social mission is explicit and central. This opinion is also in line with the statement [18], which states that social entrepreneurs uphold social aspects higher than usual. The field of social entrepreneurship has thus become a large tent (Martin and Osberg 2007). However, the definitions of social enterprise and social entrepreneurship seem to have different versions due to diverse academic backgrounds, geographic locations, and the economic developmental context of the countries [19], [7].

For this study, the authors have developed the definition by following the explanations by [7] and [20] that social entrepreneurship is a business activity carried out by a person or group of people who are driven by a range of motivations and values, which include but are not limited to prosocial concerns with innovative ways through enterprise operations, which could be either a social enterprise, non-profit, private or public institution. Previous researchers have done several bibliometric analyses in Table 1, detailed previous research, including the sources of the database and their main findings. 
Table 1. Several bibliometric analyzes that have been done by previous researchers on the topic of social entrepreneurship

\begin{tabular}{|c|c|c|c|}
\hline $\begin{array}{c}\text { Author(s) } \\
\text { \& Year }\end{array}$ & $\begin{array}{c}\text { Number of } \\
\text { Documents } \\
\text { Analyzed }\end{array}$ & Sources & Findings \\
\hline [6] & 2984 & $\begin{array}{l}\text { Web of Science } \\
\text { online databases }\end{array}$ & $\begin{array}{l}\text { The field with the most published documents is business } \\
\text { economics. The phrase social entrepreneurship first emerged in } \\
\text { 1964, but only after } 2003 \text { does the notion begin to draw academics' } \\
\text { attention. The number of papers continues to rise year on year. The } \\
\text { country responsible for most social entrepreneurship research is the } \\
\text { United States. The publication that has published the most on social } \\
\text { entrepreneurship research is the Journal of Bussiness Venturing, } \\
\text { which has an impact factor of } 3.265 \text {. The most prolific social } \\
\text { entrepreneurship author is Anderson AR, with } 12 \text { papers and } 539 \\
\text { citations). }\end{array}$ \\
\hline [21] & 1296 & $\begin{array}{l}\text { Web of Science } \\
\text { online databases }\end{array}$ & $\begin{array}{l}\text { The conclusions of this article include (1) identifying significant } \\
\text { academic contributions in the area and the links among them, (2) } \\
\text { charting the history of the field over time, (3) evaluating the social } \\
\text { entrepreneurship field. }\end{array}$ \\
\hline [12] & 124 & $\begin{array}{l}\text { EBSCO } \\
\text { Business Source } \\
\text { Premier, } \\
\text { Emerald, } \\
\text { JSTOR, Science } \\
\text { Direct, Springer, } \\
\text { and Wiley } \\
\text { Online. }\end{array}$ & $\begin{array}{l}\text { The authors found the business model generated from the CG } \\
\text { matrix and ECG model specifically suitable for the development of } \\
\text { SE since it is based on the three pillars of sustainability: economic, } \\
\text { social, and environmental. The social and ethical management on } \\
\text { which the ECG model builds its connections with stakeholders } \\
\text { equips it with the critical elements of SE. Consequently, from a } \\
\text { theoretical point of view, it is feasible to discover many overlaps } \\
\text { and linkages between the ECG model and SE that can be } \\
\text { strengthened. }\end{array}$ \\
\hline [22] & 2695 & $\begin{array}{l}\text { Web of Science } \\
\text { online database }\end{array}$ & $\begin{array}{l}\text { The primary conclusion is that, from the study, we can observe that } \\
\text { scientific production in this field of knowledge has accelerated in } \\
\text { recent years-still, the centrality and the search density experience } \\
\text { considerable modifications. New pathways for future study are } \\
\text { indicated. In summary, from period } 1 \text { to period } 3 \text {, we see that the } \\
\text { topic "social innovation" persists with a focus of research and the } \\
\text { article "social entrepreneurship," albeit now with less transversality } \\
\text { and development. However, the topic of "sustainability" is currently } \\
\text { the subject of research within the disciplines "social } \\
\text { entrepreneurship," "social innovation," "innovation," and "case } \\
\text { study." The same evolutionary route suffered the subject of "social } \\
\text { enterprise." }\end{array}$ \\
\hline [8] & 154 & $\begin{array}{l}\text { Social enterprise } \\
\text { journal }\end{array}$ & $\begin{array}{l}\text { The bibliometric analysis highlighted the tendency towards } \\
\text { integration with a significant presence of co-operation between } \\
\text { authors and institutions, where } 70 \text { percent of articles produced by } \\
\text { the most prolific authors were written in co-authorship and } 30 \\
\text { percent of them by more than four different authors, which enriches } \\
\text { the development of the field. The authorship pattern also reveals a } \\
\text { high degree of internalization of the field, with } 289 \text { additional } \\
\text { writers, from institutions from } 30 \text { different nations publishing } \\
\text { papers about } 40 \text { countries on all five continents. The research } \\
\text { strategy primarily utilized was qualitative through the use of case } \\
\text { studies. }\end{array}$ \\
\hline
\end{tabular}




\section{Methodology: A Bibliometric Analysis}

The objective of this research is to evaluate how are social entrepreneurship publications categorized. Then, to know the trend of social entrepreneurship research, which research subjects are the subject of more publications, and to assess future social entrepreneurship themes that give prospects for further inquiry.

\subsection{Search for Specific Journals on the Topic of Social Entrepreneurship}

A bibliometric review is commonly utilized in scientific areas. It focuses on a quantitative analysis of journal papers, books, or other kinds of written communication [23]. Work begins with searching in Google databases related to journals that specifically address the topic of social entrepreneurship. Several journals specifically address this topic, and there is the Journal of Social Entrepreneurship (JSE), Social Enterprise Journal (SEJ), Journal of Global Business and Social Entrepreneurship (GBSE), and International Journal of Social Entrepreneurship and Innovations (IJSEI).

\subsection{Journal Reputation}

At this stage, journals that have good standing have been selected and are still in progress today. Table 2 shows the results of the journal screening.

Table 2. Profile of a journal with a special topic on social entrepreneurship

\begin{tabular}{|l|c|c|c|c|}
\hline \multicolumn{1}{|c|}{ Point of View } & JSE & SEJ & GBSE & IJSEI \\
\hline Publisher & Taylor \& Francis & Emerald & GBSE Global & Inderscience \\
\hline First published & 2010 & 2005 & 2015 & 2011 \\
\hline Last published & 2020 (on going) & 2020 (on going) & 2020 (on going) & 2018 \\
\hline Scopus Indexed & Yes & Yes & No & No. \\
\hline Web of Science Indexed & No & No & No & No \\
\hline Impact factor by SJR & 0.46 & N/A & N/A & N/A \\
\hline
\end{tabular}

Based on Table 2, there are only two journals indexed by Scopus, namely JSE and SEJ. JSE has the best reputation among the four journals because it has a high impact factor from SJR to be classified in Q2. However, SEJ is also essential because it is the first journal specifically on social entrepreneurship.

\subsection{Journal Metrics Information}

This section explicitly describes the profiles and metrics of the two selected journals, namely SEJ and JSE. Table 3 shows some important things to know from the two chosen journals. This metric information is obtained from metadata information using the Publish or Perish (PoP) application.

Table 3. Metrics information of selected journals

\begin{tabular}{|l|c|c|}
\hline \multicolumn{1}{|c|}{ Metrics data } & JSE & SEJ \\
\hline Publication years & $2010-2020$ & 15 \\
\hline Citation years & 10 & 248 \\
\hline Papers & 205 & 8763 \\
\hline Citations & 5812 & 584.2 \\
\hline Cites/year & 581.2 & 36.06 \\
\hline Cites/paper & 28.63 & 2.12 \\
\hline Authors/paper & 2.26 & 50 \\
\hline h-index & 36 & 88 \\
\hline g-index & 71 & 37 \\
\hline hI, norm & 27 & 2.47 \\
\hline hI, annual & 2.7 & \\
\hline
\end{tabular}

\subsection{Reference Management}

After all, articles have been downloaded from the two journal websites. The next step is tidying references using the Mendeley application. References are needed to ensure that the metadata for each article is complete, such as information about the author, keywords, abstracts, and other information.

\subsection{Bibliometric Analysis}

After all of the article's metadata is confirmed to be complete, the next step is to conduct a 
bibliometric analysis. The application used in analyzing bibliometrics in this article is VosViewer.

\section{Results and Discussion}

To address this paper's first objective regarding how social entrepreneurship articles are classified in JSE and SEJ utilizing VosViewer software, producing a map based on text data using the title and abstract fields, with the binary counting approach, there are 8594 keywords discovered.
With a minimum number of occurrences of a period of 10 times, 234 thresholds were found. However, for each of the 234 words, a relevance score will be generated. Based on this score, the most relevant phrases will be picked automatically by default as much as 60 percent, so we obtain the 140 most acceptable words. However, the verification process must be done manually by eliminating unrelated words, such as editorial, sample, abstract, and others. Thus, the total number of words that can be included in making a map is 100 words.

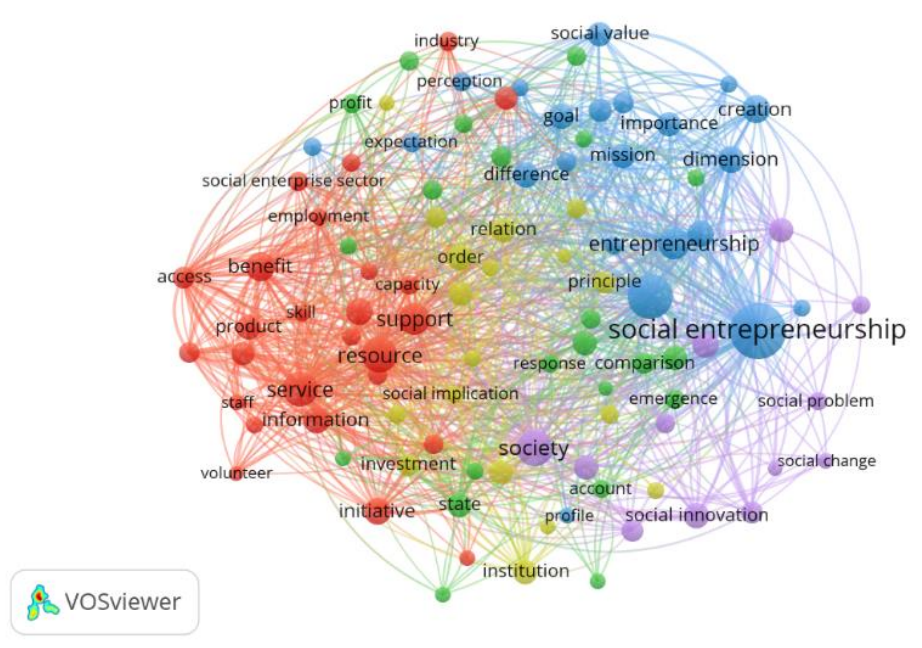

Fig.1: Network visualization map of keywords

Based on Figure 1, several clusters are characterized by blue, purple, yellow, red, and green. Based on the total articles from JSE and SEJ, several words in the cluster appear most often. These clusters are an indication that, to date, there are five classifications of articles published by JSE and SEJ. More detail can be seen in table 4 .

Table 4. Clusters and keywords therein

\begin{tabular}{|c|c|c|c|}
\hline Cluster & $\begin{array}{l}\text { Total } \\
\text { items }\end{array}$ & $\begin{array}{l}\text { Most frequent } \\
\text { keywords } \\
\text { (occurrences) }\end{array}$ & Keywords \\
\hline 1 & 26 & $\begin{array}{l}\text { resource (52), service } \\
(52), \text { support }(44)\end{array}$ & $\begin{array}{l}\text { ability, access, benefit, capacity, company, condition, employee, employment, England, } \\
\text { income, industry, information, initiatives, lesson, manager, member, person, product, } \\
\text { resource, sense, service, skill, social enterprise sector, staff, support, volunteer }\end{array}$ \\
\hline 2 & 22 & $\begin{array}{l}\text { state }(28) \text {, environment } \\
(28) \text {, action }(27)\end{array}$ & $\begin{array}{l}\text { account, action, application, attempt, Australia, comparison, complexity, cooperative, } \\
\text { emergence, environment, evolution, lack, leader, limitation, performance, profit, } \\
\text { response, ses, social economy, social enterprise model, social enterprises, state }\end{array}$ \\
\hline 3 & 22 & $\begin{array}{l}\text { social entrepreneurship } \\
\text { (121), entrepreneur } \\
\text { (80), entrepreneurship } \\
(43)\end{array}$ & $\begin{array}{l}\text { assumption, creation, difference, dimension, diversity, effect, entrepreneur, } \\
\text { entrepreneurship, expectation, extent, goal, importance, light, mission, motivation, } \\
\text { operation, perception, profile, social capital, social entrepreneurship, social mission, } \\
\text { social value }\end{array}$ \\
\hline 4 & 18 & $\begin{array}{l}\text { policymaker (31), } \\
\text { institution (27), } \\
\text { governance (26), } \\
\text { government (26) }\end{array}$ & $\begin{array}{l}\text { difficulty, discourse, effectiveness, governance, government, identity, institution, } \\
\text { investment, legitimacy, mechanism, order, policymaker, principle, relation, risk, social } \\
\text { implication, variety }\end{array}$ \\
\hline 5 & 12 & $\begin{array}{l}\text { society (55), } \\
\text { innovation (31), social } \\
\text { innovation (30) }\end{array}$ & $\begin{array}{l}\text { change, innovation, phenomenon, region, social, social change, social innovation, social } \\
\text { problem, social venture, society, solution, venture }\end{array}$ \\
\hline
\end{tabular}


Then, to answer the trend of social entrepreneurship research, we can see the answer actually from the cluster itself. Figure 2 shows the density visualization of articles published by JSE and SEJ. Cluster 1, with the words resource and service being the words that appear most often.

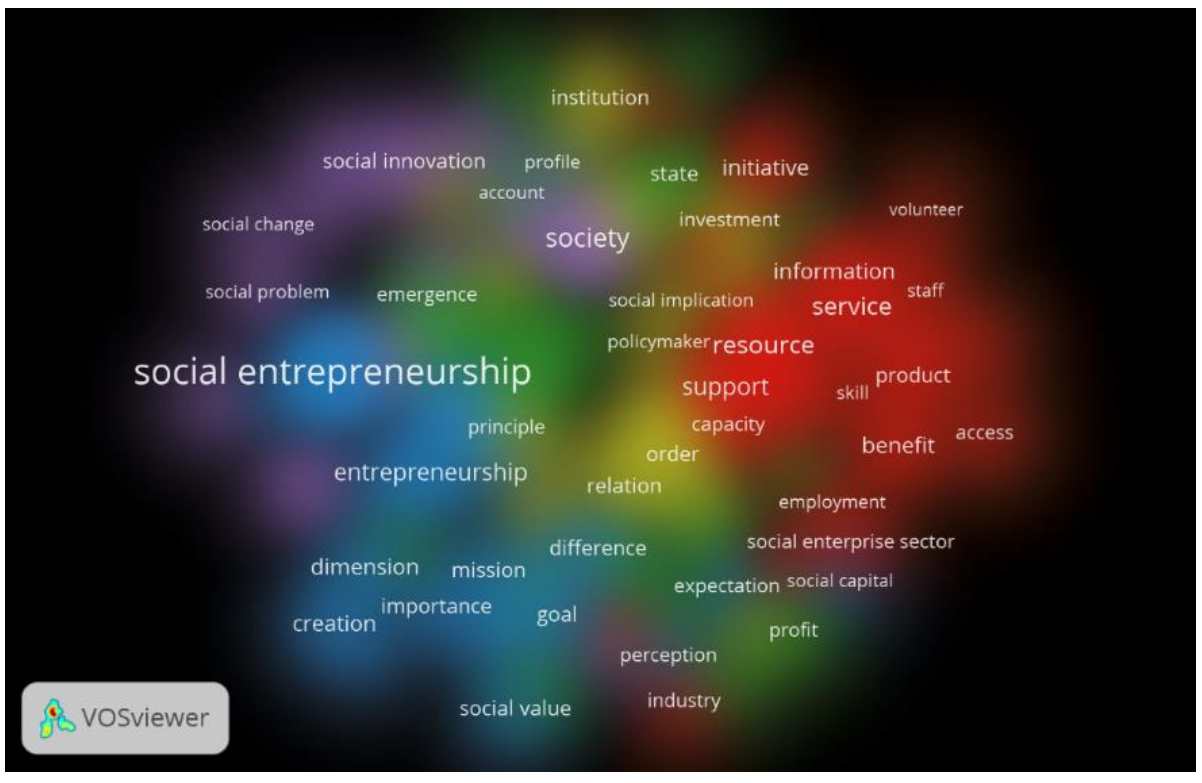

Fig.2: Density visualization map of keywords

There is a cluster of the results of this mapping that appears at least in the keyword, namely cluster 5. This cluster covers topics about innovation and social innovation. Also, some words rarely appear in keywords in each cluster, such as social entrepreneurial intention, social entrepreneurship model, or those related to institutions and government. The meaning is, there are still research gaps that are very likely to become a trend in the future, which, of course, is adapted to current world conditions and the end. From the researcher's side, there are also five clusters, as presented in Figure 3.

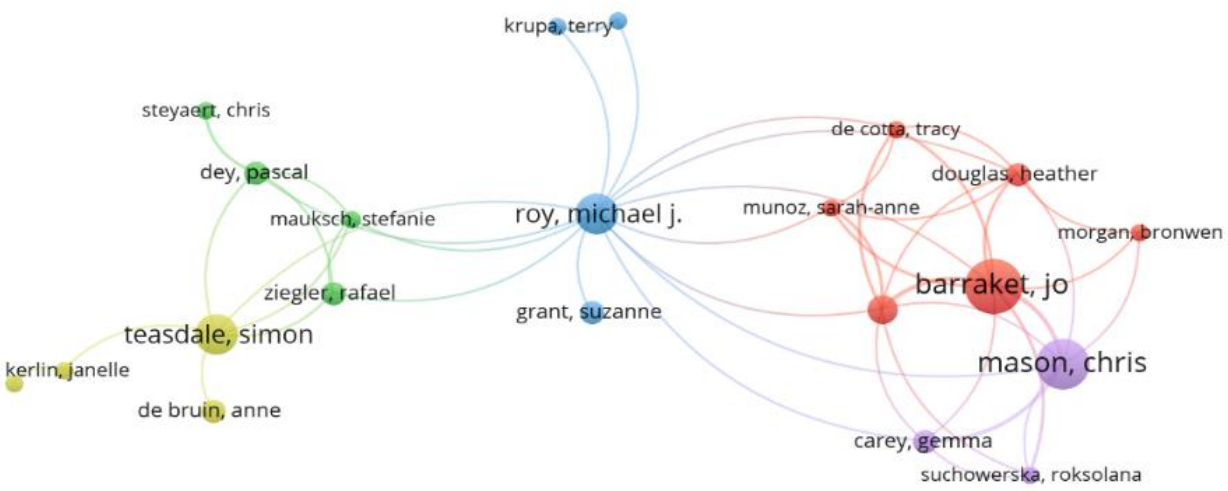

\& Vosviewer

Fig.3: Network visualization map of authors 
Based on Figure 3, it can be seen that there are five big names from each cluster that are marked with large dots in each cluster. In the picture, only writers who are related in their publications are shown. However, suppose the authorship of the authorship is eliminated. In that case, the writer with the most significant point is Alex Nicholls with 17 documents and the majority in JSE, then Jo Barraket both in JSE and SEJ with nine papers and Chris Mason with eight articles, the majority of which are in SEJ. In Table 5, it is known that the documents from the two most cited journals, along with other detailed elements, were calculated on May 18, 2020.

Table 5. The top ten cited documents in JSE and SEJ

\begin{tabular}{|c|c|c|c|c|c|}
\hline \multicolumn{3}{|c|}{ JSE } & \multicolumn{3}{|c|}{ SEJ } \\
\hline Citations & Authors and year & Title & Citations & $\begin{array}{c}\text { Authors and } \\
\text { year }\end{array}$ & Title \\
\hline 1306 & {$[24]$} & $\begin{array}{l}\text { Conceptions of social enterprise } \\
\text { and social entrepreneurship in } \\
\text { Europe and the United States: } \\
\text { convergences and divergences }\end{array}$ & 901 & [25] & $\begin{array}{l}\text { Social enterprise in Europe: recent } \\
\text { trends and developments }\end{array}$ \\
\hline 216 & [26] & $\begin{array}{l}\text { The institutionalization of social } \\
\text { investment: the interplay of } \\
\text { investment logics and investor } \\
\text { rationalities }\end{array}$ & 520 & [27] & $\begin{array}{l}\text { A research agenda for social } \\
\text { entrepreneurship }\end{array}$ \\
\hline 176 & {$[28]$} & $\begin{array}{l}\text { Exploring the motivation of } \\
\text { nascent social entrepreneurs }\end{array}$ & 451 & [29] & $\begin{array}{l}\text { Social enterprise: An international } \\
\text { overview of its conceptual } \\
\text { evolution and legal } \\
\text { implementation }\end{array}$ \\
\hline 169 & {$[30]$} & $\begin{array}{l}\text { Identifying the drivers of social } \\
\text { entrepreneurial impact: } \\
\text { theoretical development and an } \\
\text { exploratory empirical test of } \\
\text { SCALERS }\end{array}$ & 259 & [31] & $\begin{array}{l}\text { Eight paradoxes of the social } \\
\text { enterprise research agenda }\end{array}$ \\
\hline 158 & {$[32]$} & $\begin{array}{l}\text { Patterns of meaning in the social } \\
\text { entrepreneurship literature: a } \\
\text { research platform }\end{array}$ & 223 & [33] & $\begin{array}{l}\text { Emerging models of social } \\
\text { enterprise in Eastern Asia: a } \\
\text { cross- country analysis }\end{array}$ \\
\hline 130 & {$[34]$} & $\begin{array}{l}\text { Analyzing social } \\
\text { entrepreneurship from an } \\
\text { institutional perspective: } \\
\text { evidence from Spain }\end{array}$ & 187 & [35] & $\begin{array}{l}\text { "Balance": the development of a } \\
\text { social enterprise business } \\
\text { performance analysis tool }\end{array}$ \\
\hline 116 & [36] & $\begin{array}{l}\text { Playing with numbers: a } \\
\text { methodological critique of the } \\
\text { social enterprise growth myth }\end{array}$ & 177 & [7] & $\begin{array}{l}\text { Social enterprise and social } \\
\text { entrepreneurship research and } \\
\text { theory: A bibliometric analysis } \\
\text { from } 1991 \text { to } 2010\end{array}$ \\
\hline 115 & {$[37]$} & $\begin{array}{l}\text { Understanding value creation in } \\
\text { social entrepreneurship: the } \\
\text { importance of aligning mission, } \\
\text { strategy and impact } \\
\text { measurement }\end{array}$ & 171 & {$[38]$} & $\begin{array}{l}\text { Growing the social enterprise - } \\
\text { issues and challenges }\end{array}$ \\
\hline 105 & [39] & $\begin{array}{l}\text { Diversification reconsidered: the } \\
\text { risks and rewards of revenue } \\
\text { concentration }\end{array}$ & 168 & [40] & $\begin{array}{l}\text { Social enterprise and social } \\
\text { entrepreneurship: where have we } \\
\text { reached? A summary of issues and } \\
\text { discussion points }\end{array}$ \\
\hline 100 & {$[41]$} & $\begin{array}{l}\text { Creating shared value in the } \\
\text { hybrid venture arena: a business } \\
\text { model innovation perspective }\end{array}$ & 166 & [42] & $\begin{array}{l}\text { A conceptual model for social } \\
\text { entrepreneurship directed toward } \\
\text { social impact on society }\end{array}$ \\
\hline
\end{tabular}

In the period 2008-2011, it can be seen that the document on social entrepreneurship was the most explicitly cited. The most recent materials tend not to be cited much, except the authors who have researched this field before, and they are pretty well-known. Then, to see which research topics are the subject of more publications, we can see them through Table 6. 
Table 6. The 15 most and fewer occurrences terms in JSE and SEJ

\begin{tabular}{|c|c|c|c|}
\hline \multicolumn{2}{|c|}{ Most occurrences } & \multicolumn{2}{c|}{ Fewer occurrences } \\
\hline Occurrences & Term & 10 & Term \\
\hline 185 & Entrepreneur & 11 & Commercial venture \\
\hline 135 & Framework & 11 & Women social entrepreneur \\
\hline 101 & Sector & 12 & Interaction \\
\hline 87 & Social innovation & 12 & Marketing \\
\hline 74 & Service & 12 & Civil society \\
\hline 70 & Strategy & 12 & Cocial support \\
\hline 56 & Effect & 12 & Mental illness \\
\hline 54 & Person & 12 & Leadership \\
\hline 54 & Policy & 12 & NGO \\
\hline 52 & Outcome & 13 & Policymaker \\
\hline 50 & Benefit & 13 & Social network \\
\hline 49 & Motivation & 14 & Social implication \\
\hline 45 & Influence & 14 & 15 \\
\hline
\end{tabular}

In addition to explaining which subjects appear most frequently in publications, Table 6 also describes the last purpose of this paper, namely, what are future social entrepreneurship topics that provide opportunities for further research. Issues that can be an opportunity to be explored in more detail are more specific and lead to the implications or measurements of the social enterprise that has been run. Topics such as

\section{Conclusions}

The current study evaluated a group of 453 publications with themes relevant to social entrepreneurship. The papers were selected from the Journal of Social Entrepreneurship and Social Enterprise Journal. In the framework of this study, we conclude that JSE and SEJ have a more substantial influence on the field of social entrepreneurship because they both specialized in social entrepreneurship themes. Social entrepreneurship articles are classified into five clusters. The trend of social entrepreneurship research is more on the business side and entrepreneurs. Several topics often appear in publications, such as social innovation, strategy,

\section{References:}

[1] J. Mair, "Social entrepreneurship: Taking stock and looking ahead," Handb. Res. Soc. Entrep., vol. 3, pp. 15-28, 2010, doi: $10.4337 / 9781849804684.00007$.

[2] N. Ayob, C. S. Yap, D. A. Sapuan, and M. Z. A. Rashid, "Social Entrepreneurial marketing and consumers have also not been much researched on JSE and SEJ. At the same time, issues such as strategy, the influence of a variable on other variables, and social innovation have been studied quite a lot. Similarly, topics related to entrepreneurs themselves, such as their characteristics, intensities, also quite a lot emerged.

and the influence of one variable on another. Topics that have rarely appeared in JSE and SEJ are commercial ventures, social impact measurement, and women social entrepreneurs.

The current study has at least two shortcomings. First, the study is primarily exclusively based on JSE and SEJ. Second, although this study employed conventional tools (PoP software, the VOSviewer, and Mendeley), subjective judgments by authors exist and might potentially lead to the introduction of mistakes. Future research should employ a bigger sample size by incorporating additional publications while not indexed by Scopus. In addition, a comparison of the findings of an analysis using alternative bibliometric analysis tools (such as BibExcel and HistCite) is advised.

Intention among Business Undergraduates: An Emerging Economy Perspective," Gadjah Mada Int. J. Bus., vol. 15, no. 3, p. 249, Sep. 2014, doi: 10.22146/gamaijb.5470.

[3] J. G. Dees, "Taking social entrepreneurship 
seriously," Society, vol. 44, no. 3, pp. 2431, 2007, doi: 10.1007/BF02819936.

[4] A. Fowler, "NGDOS as a moment in history: Beyond aid to social entrepreneurship or civic innovation?," Third World Q., vol. 21, no. 4, pp. 637-654, 2000, doi: 10.1080/713701063.

[5] B. J. Boschee and J. Mcclurg, "Toward a better understanding of social entrepreneurship: Some important distinctions," Chief Exec., pp. 1-7, 2003, [Online]. Available: http://www.sealliance.org/better_understanding.pdf.

[6] A. Rey-Martí, D. Ribeiro-Soriano, and J. L. Sánchez-García, "Giving back to society: Job creation through social entrepreneurship," J. Bus. Res., vol. 69, no. 6, pp. 2067-2072, 2016, doi: 10.1016/j.jbusres.2015.12.010.

[7] M. L. Granados, V. Hlupic, E. Coakes, and S. Mohamed, "Social enterprise and social entrepreneurship research and theory," Soc. Enterp. J., vol. 7, no. 3, pp. 198-218, 2011, doi: $10.1108 / 17508611111182368$.

[8] M. Dionisio, "The evolution of social entrepreneurship research: a bibliometric analysis," Soc. Enterp. J., vol. 15, no. 1, pp. 22-45, 2019, doi: 10.1108/SEJ-05-20180042 .

[9] A. M. Peredo and M. McLean, "Social entrepreneurship: A critical review of the concept," J. World Bus., vol. 41, no. 1, pp. 56-65, 2006, doi: 10.1016/j.jwb.2005.10.007.

[10] C. P. Gonçalves, K. Carrara, and R. M. Schmittel, "The Phenomenon of Social Enterprises: Are We Keeping Watch on This Cultural Practice?," Voluntas, vol. 27, no. 4, pp. 1585-1610, 2016, doi: 10.1007/s11266-015-9624-9.

[11] J. C. Braga, T. Proença, and M. R. Ferreira, "Motivations for social entrepreneurship Evidences from Portugal," Tékhne, vol. 12, no. October 2018, pp. 11-21, 2014, doi: 10.1016/j.tekhne.2015.01.002.

[12] V. Campos, J. R. Sanchis, and A. Ejarque, "Social entrepreneurship and Economy for the Common Good: Study of their relationship through a bibliometric analysis," Int. J. Entrep. Innov., 2019, doi: $10.1177 / 1465750319879632$.

[13] W. B. Gartner, "A conceptual framework for describing the phenomenon of New Venture Creation," Entrep. as Organ. Sel. Pap. William B. Gart., vol. 10, no. 4, pp. 1-
11, 2016, doi: 10.5465/amr.1985.4279094.

[14] A. Shapero and L. Sokol, "The Social Dimensions of Entrepreneurship Here is the Coronavirus related research on SSRN Related eJournals," 2009.

[15] J. Boschee, "Merging mission and money: A board member's guide to social entrepreneurship," Natl. Cent. Non-profit Boards, pp. 1-12, 1998, [Online]. Available:

http://www.socialent.org/pdfs/MergingMissi on.pdf.

[16] C. Borgaza, S. Depredi, and G. Galera, "Interpreting social enterprises," Rev. Adm., vol. 47, no. 3, pp. 398-409, 2012, doi: 10.5700/rausp1046.

[17] K. Kurniawan and Y. Iskandar, "A Systematic Literature Review of The Importance of Sustainable Business Strategy," Wseas Trans. Environ. Dev., vol. 17, pp. 829-839, 2021, doi: 10.37394/232015.2021.17.78.

[18] R. L. Martin and S. Osberg, "Social Entrepreneurship: The Case for Definition," Stanford Soc. Innov. Rev., pp. 27-39, 2007, doi: 10.1002/anie.201310158.

[19] J. Defourny and M. Nyssens, "EMES Working Papers Series The EMES approach of social enterprise in a comparative perspective," no. 12, p. 44, 2012.

[20] U. Stephan and A. Drencheva, The person in social entrepreneurship: A systematic review of research on the social entrepreneurial personality, no. January. 2017.

[21] P. Kumar, H. Balaji, and G. Narayanamurthy, "Mapping the Intellectual Structure of Social Entrepreneurship Research: A Citation / Co-citation Analysis," J. Bus. Ethics, vol. 0, no. 0, p. 0, 2019, doi: 10.1007/s10551-019-04129-4.

[22] L. Farinha, J. R. Sebastião, C. Sampaio, and J. Lopes, "Social innovation and social entrepreneurship: discovering origins , exploring current and future trends," Int. Rev. Public Nonprofit Mark., vol. 17, pp. 77-96, 2020.

[23] R. Heersmink, J. van den Hoven, N. J. van Eck, and J. den van Berg, "Bibliometric mapping of computer and information ethics," Ethics Inf. Technol., vol. 13, no. 3, pp. 241-249, 2011, doi: 10.1007/s10676011-9273-7.

[24] J. Defourny and M. Nyssens, "Conceptions of social enterprise and social 
entrepreneurship in Europe and the United States: Convergences and divergences," $J$. Soc. Entrep., vol. 1, no. 1, pp. 32-53, 2010, doi: 10.1080/19420670903442053.

[25] J. Defourny and M. Nyssens, "Social enterprise in Europe: recent trends and developments," Soc. Enterp. J., vol. 4, no. 3, pp. 202-228, 2008, doi: $10.1108 / 17508610810922703$.

[26] A. Nicholls, The institutionalization of social investment: The interplay of investment logics and investor rationalities, vol. 1, no. 1. 2010.

[27] H. Haugh, "The importance of theory in social enterprise research," Soc. Enterp. J., vol. 8, no. 1, pp. 7-15, 2012, doi: $10.1108 / 17508611211226557$.

[28] A. J. Germak and J. A. Robinson, "Exploring the Motivation of Nascent Social Entrepreneurs," J. Soc. Entrep., vol. 5, no. 1, pp. 5-21, 2014, doi: 10.1080/19420676.2013.820781.

[29] G. Galera and C. Borzaga, "Social enterprise: An international overview of its conceptual evolution and legal implementation," Soc. Enterp. J., vol. 5, no. 3 , pp. 210-228, 2009, doi: $10.1108 / 17508610911004313$.

[30] P. N. Bloom and B. R. Smith, "Identifying the drivers of social entrepreneurial impact: Theoretical development and an exploratory empirical test of SCALERS," J. Soc. Entrep., vol. 1, no. 1, pp. 126-145, 2010, doi: 10.1080/19420670903458042.

[31] K. Peattie and A. Morley, "Eight paradoxes of the social enterprise research agenda," Soc. Enterp. J., vol. 4, no. 2, pp. 91-107, 2008, doi: 10.1108/17508610810901995.

[32] T. L. Hill, T. H. Kothari, and M. Shea, "Patterns of meaning in the social entrepreneurship literature: A research platform," J. Soc. Entrep., vol. 1, no. 1, pp. 5-31, 2010, doi: 10.1080/19420670903442079.

[33] J. Defourny and S. Kim, "Emerging models of social enterprise in Eastern Asia: a cross- country analysis," Soc. Enterp. J., vol. 7, no. 1, pp. 86-111, 2011, doi: 10.1108/17508611111130176.

[34] D. Urbano, N. Toledano, and D. R. Soriano, "Analyzing social entrepreneurship from an institutional perspective: Evidence from Spain,” J. Soc. Entrep., vol. 1, no. 1, pp. 5469, 2010, doi: $10.1080 / 19420670903442061$.
[35] M. Bull, “'Balance': the development of a social enterprise business performance analysis tool," Soc. Enterp. J., vol. 3, no. 1, pp. 49-66, 2007, doi: $10.1108 / 17508610780000721$.

[36] S. Teasdale, F. Lyon, and R. Baldock, "Playing with Numbers: A Methodological Critique of the Social Enterprise Growth Myth," J. Soc. Entrep., vol. 4, no. 2, pp. 113-131, 2013, doi: 10.1080/19420676.2012.762800.

[37] J. Ormiston, K. Charlton, M. S. Donald, and R. G. Seymour, "Overcoming the Challenges of Impact Investing: Insights from Leading Investors," J. Soc. Entrep., vol. 6, no. 3, pp. 352-378, 2015, doi: 10.1080/19420676.2015.1049285.

[38] B. Hynes, "Growing the social enterprise issues and challenges," Soc. Enterp. J., vol. 5, no. 2, pp. 114-125, 2009, doi: 10.1108/17508610910981707.

[39] P. Frumkin and E. K. Keating, "Diversification Reconsidered: The Risks and Rewards of Revenue Concentration," $J$. Soc. Entrep., vol. 2, no. 2, pp. 151-164, 2011, doi: 10.1080/19420676.2011.614630.

[40] J. L. Thompson, "Social enterprise and social entrepreneurship: where have we reached?," Soc. Enterp. J., vol. 4, no. 2, pp. 149-161, 2008, doi: 10.1108/17508610810902039.

[41] J. Florin and E. Schmidt, "Creating Shared Value in the Hybrid Venture Arena: A Business Model Innovation Perspective," J. Soc. Entrep., vol. 2, no. 2, pp. 165-197, 2011, doi: 10.1080/19420676.2011.614631.

[42] H. Jiao, "A conceptual model for social entrepreneurship directed toward social impact on society," Soc. Enterp. J., vol. 7, no. 2, pp. 130-149, 2011, doi: $10.1108 / 17508611111156600$

\section{Contribution of Individual Authors to the Creation of a Scientific Article (Ghostwriting Policy)}

Yusuf Iskandar designed the analysis with Publish or Perish and downloaded the articles to be stored in the database.

Joeliaty performs database checks and analysis preparation on VOSViewer.

Umi Kaltum performs analysis on VOSViewer and design discussion. 
Hilmiana conducted studies and discussions in the discussion section and checked the completeness of tables and figures.

\section{Sources of Funding for Research Presented in a Scientific Article or Scientific Article Itself}

This paper was funded from the personal funds of each author.

Creative Commons Attribution License 4.0 (Attribution 4.0 International, CC BY 4.0)

This article is published under the terms of the

Creative Commons Attribution License 4.0

https://creativecommons.org/licenses/by/4.0/deed.e 